\title{
Respon Hasil dan Kadar Total Flavonoid Umbi Bawang Dayak (Eleutherine palmifolia (L.) Merr) terhadap Pemberian Naungan
}

\section{The Response of Yield and Flavonoid Total Content of Dayak Onion (Eleutherine palmifolia (L.) Merr) on Shading Given}

\author{
Rina Ekawati ${ }^{1 *}$ \\ ${ }^{1}$ Politeknik Lembaga Pendidikan Perkebunan, Jl. LPP 1A Balapan Yogyakarta 55222, Indonesia \\ *Email korespondensi: rina.ekawati1410@gmail.com
}

Diterima: 22 Juli 2020 / Disetujui: 04 September 2020

\begin{abstract}
The production and metabolite content, especially flavonoid of Eleutherine palmifolia was affected of environmental factors, especially shading. Dayak onion is a functional vegetable that can used as medicinal plant because contained of secondary metabolite that have pharmacology effect. This research was aimed to provide information the effect of low light intensity (shading) on the growth, physiology and production of bawang dayak. This experiment was conducted at Caturtunggal, Karang Gayam, Depok Sleman, from September 2019 to February 2020 (six months). The experiment was laid out in nested design with single factor with two treatments (Without shading and shading net $75 \%$ ). Each treatment was repeated three times. The result of the research showed that shading $75 \%$ was affected on the weight of wet and dry biomass (shoot and root) on bawang dayak. Shading decrease number of tiller, number of bulb per plant, and weight of bulb per plant. Total flavonoid content was not affected by shading.
\end{abstract}

Keywords: Dayak onion, flavonoid, shade, yield

\section{ABSTRAK}

Produksi dan kandungan metabolit bawang dayak tidak terlepas dari faktor lingkungan yang mempengaruhinya, salah satunya yaitu naungan. Tanaman bawang dayak sangat berpotensi sebagai obat herbal dengan berbagai kegunaan dan aktivitas farmakologis yang dapat dikaitkan dengan kandungan metabolit sekunder tanaman, khususnya kandungan flavonoid. Penelitian ini bertujuan untuk menerangkan pengaruh intensitas cahaya rendah (naungan) terhadap produksi dan kandungan metabolit tanaman bawang dayak. Percobaan ini dilakukan di Caturtunggal, Karang Gayam, Depok Sleman, dari bulan September 2019 sampai dengan bulan Februari 2020. Penelitian ini menggunakan rancangan petak tersarang sederhana dengan perlakuan, yaitu tanpa naungan (NO) dan naungan paranet $75 \%$ (N1). Setiap perlakuan diulang tiga kali. Data diuji dengan menggunakan uji -student pada taraf nyata 5\%. Hasil menunjukkan bahwa pemberian naungan $75 \%$ berpengaruh nyata lebih rendah terhadap jumlah anakan dan komponen produksi tanaman bawang dayak. Naungan menurunkan bobot basah dan kering biomassa tanaman (tajuk dan akar), jumlah anakan, jumlah umbi/tanaman, dan bobot umbi/tanaman. Kandungan total flavonoid tidak dipengaruhi oleh naungan.

Kata kunci: bawang Dayak, flavonoid, hasil, naungan

\section{PENDAHULUAN}

Krisis kesehatan yang dialami oleh masyarakat Indonesia dan dunia terkait pandemi COVID-19 tahun 2020 ini mampu mengubah kehidupan manusia, salah satunya yaitu mengenai kesehatan tubuh. Peningkatan sistem kekebalan (immune) tubuh yang menjadi salah satu kunci utama dalam mencegah penularan COVID-19. Sistem kekebalan tubuh dapat ditingkatkan dengan salah satunya yaitu memanfaatkan/mengkonsumsi tanaman obat yang memiliki efek farmakologis. Beberapa efek/aktivitas farmakologis tersebut seperti: sebagai antiinflamasi, antikanker, antimikroba, antidiabetes, antihipertensi dan antivirus (Prayitno, Mukti, \& Lagiono, 2018). Salah satu jenis tanaman obat yang mulai banyak dikembangkan, khususnya di daerah Kalimantan karena manfaatnya, yaitu bawang dayak (Eleutherine palmifolia (L.) Merr) sebagai tanaman obat dan pestisida alami (Egra, Ayu Sekarsari, Kuspradini, \& Mitsunaga, 2019). Bahkan, sekarang tanaman tersebut sudah mulai dikembangkan untuk daerah di luar Kalimantan, seperti di daerah Jawa Barat.

Tanaman bawang dayak memiliki banyak jenis dengan bentuk, jenis dan dengan nama daerah yang beragam, seperti: bawang tiwai (Eleutherine americana Merr.), bawang sabrang, bawang hutan, bawang seribu tawar (Dayak Meratus, Banjar), dan bawang hantu. Untuk membedakan dengan jenis bawang lainnya, tanaman bawang dayak memiliki ciri spesifik yaitu umbi tanaman berwarna merah menyala dengan permukaan yang sangat licin. Letak daun berpasangan dengan komposisi daun bersirip ganda. Tipe pertulangan daun sejajar dengan tepi daun licin dan bentuk daun berbentuk pita berbentuk garis (Galingging, 2009). Umbi bawang dayak termasuk ke dalam famili Iridaceae dan 
berwarna merah cerah yang menyerupai bawang merah (Puspadewi, Adirestuti, \& Menawati, 2013).

Bawang dayak dimanfaatkan oleh masyarakat lokal sebagai obat berbagai jenis penyakit, yaitu kanker payudara, hipertensi, kencing manis (Diabetus melitus), menurunkan kolesterol, obat bisul, kanker usus, dan mencegah stroke (Galingging, 2009). Manfaat bawang dayak sebagai tanaman obat tidak terlepas dari kandungan fitokimia yang terkandung, seperti: senyawa flavonoid, polifenol, alkaloid, quinon, tanin, steroid, monoterpenoid, dan sesquiterpenoid (Puspadewi et al., 2013). Umbi bawang dayak mengandung senyawa bioaktif, seperti fenol, flavonoid, dan turunannya yang berperan dalam mencegah berbagai jenis penyakit (Wijayanti \& Hasyati, 2018).

Produksi dan kandungan metabolit bawang dayak tidak terlepas dari faktor lingkungan yang mempengaruhinya, salah satunya yaitu pemberian naungan. Naungan berkaitan dengan intensitas cahaya matahari yang dapat mempengaruhi laju fotosintesis dan pertumbuhan dari suatu tanaman (Audina, Maxiselly, \& Rosniawaty, 2016). Beberapa hasil penelitian menunjukkan pengaruh intensitas cahaya matahari yang berbeda-beda di setiap jenis tanaman, seperti pada kangkung darat (Wulandari, Haryanti, \& Izzati, 2016), kedelai (Handriawan, Respatie, \& Tohari, 2016), Kacip Fatimah (Karimi, Jaafar, Ghasemzadeh, \& Ibrahim, 2013), lamtoro (Pradana, Putri, \& Hudaidah, 2017) dan pak-choi ungu (Zhu et al., 2017). Bawang dayak termasuk jenis tumbuhan liar dan tidak menutup kemungkinan dapat tumbuh pada kondisi lingkungan yang ternaungi. Naungan dapat bersifat alami (di bawah tegakan pohon) dan buatan (bentuk paranet). Penelitian ini diawali dengan menggunakan naungan buatan, yaitu paranet $75 \%$ karena kandungan metabolit sekunder diduga dapat meningkat seiring dengan semakin rendahnya intensitas cahaya yang diterima (persentase naungan semakin tinggi).

Tanaman bawang dayak sangat berpotensi sebagai obat herbal dengan berbagai kegunaan dan aktivitas farmakologis yang dapat dikaitkan dengan kandungan metabolit sekunder tanaman sehingga perlu penelitian yang lebih lanjut (Naspiah, Iskandar, \& Moelyono, 2014). Dalam penelitian ini menekankan dari sisi faktor lingkungan yaitu budidaya bawang dayak pada pemberian naungan paranet $75 \%$.

Adapun tujuan dari penelitian ini adalah untuk dapat memberikan informasi mengenai pengaruh pemberian naungan paranet $75 \%$ terhadap produksi dan kandungan total flavonoid bawang dayak yang terbaik. Hasil dari penelitian ini diharapkan dapat memberikan informasi ilmiah mengenai produksi dan kandungan metabolit sekunder bawang dayak melalui perlakuan naungan yang diberikan serta dapat digunakan sebagai tambahan informasi dalam teknis budidaya tanaman bawang dayak.

\section{BAHAN DAN METODE}

Penelitian dilaksanakan pada Bulan September 2019 sampai dengan Bulan Februari 2020 (6 bulan) di Caturtunggal, Karang Gayam, Depok Sleman dengan percobaan dilakukan pada polibag. Untuk perlakuan naungan menggunakan paranet $75 \%$. Naungan paranet dibuat dengan ukuran $5 \mathrm{~m}$ x $3 \mathrm{~m}$. Naungan tersebut menggunakan tiang penyangga dari bambu dan menutupi seluruh petak percobaan. Bahan yang digunakan dalam penelitian adalah umbi bawang dayak aksesi Kalimantan, paranet 75\%, tanah top soil, arang sekam, kompos, polibag ukuran 35 x $35 \mathrm{~cm}$ (bobot tanah $10 \mathrm{~kg} \mathrm{polibag}^{-1}$ ), pupuk NPK Mutiara 15-15-15 dengan dosis $500 \mathrm{~kg} \mathrm{ha}^{-1}$ (12,5 $\mathrm{g}$ polibag $^{-1}$ ) (Prasetya, 2014). Peralatan yang digunakan antara lain: bambu, selang air, alatalat budidaya secara umum, thermohygrometer, cooler box, timbangan digital, dan alat-alat penunjang penelitian lainnya (alat tulis, penggaris, plastik, label perlakuan dan gunting).

Penelitian ini menggunakan rancangan petak tersarang sederhana dengan dua (2) perlakuan, yaitu tanpa naungan (N0) dan naungan $75 \%$ (N1). Setiap perlakuan diulang tiga kali sehingga terdapat enam (6) unit percobaan. Setiap unit percobaan terdiri dari 10 tanaman (polibag) sehingga total terdapat 60 tanaman.

Pelaksanaan percobaan antara lain: (1) Seleksi benih yang sehat, warna mengkilat, kompak/tidak keropos, memiliki akar, kulit tidak luka dan berukuran seragam; (2) Persiapan media tanam. Media tanam yang digunakan adalah campuran antara tanah, arang sekam, dan kompos $(1: 1: 1)$ dengan bobot $5 \mathrm{~kg}_{\text {polibag }}{ }^{-1}$; (3) Penanaman. Bibit sebelum ditanam dipotong terlebih dahulu pada bagian ujung pangkal umbinya sekitar $0.5 \mathrm{~cm}$ untuk memecahkan masa dormansi dan mempercepat pertumbuhan tanaman, kemudian umbi ditanam dengan cara membenamkan 3/4 bagian umbi; (4) Pemupukan dasar (NPK Mutiara 15-15-15) dilakukan pada empat hari setelah tanam dengan dosis $5 \mathrm{~g} \operatorname{tanaman}^{-1}$; (5) Kegiatan pemeliharaan tanaman meliputi penyiraman dan penyiangan gulma. Penyiraman dilakukan dua hari sekali yaitu pada pagi atau sore hari. Penyiangan gulma dilakukan satu minggu sekali secara manual; (6) Kegiatan pengamatan komponen produksi tanaman dilakukan satu kali yaitu pada saat panen pada umur 17 MST (Minggu Setelah Tanam) yang meliputi: jumlah anakan, bobot basah dan kering biomassa tanaman (tajuk dan akar), jumlah umbi per tanaman, dan bobot umbi per tanaman; serta (7) Analisis kandungan total flavonoid dengan metode Spectrophotometry (Meda, Euloge, Romito, Millogo, \& Germaine, 2005). Analisis data menggunakan uji $t$-student pada taraf nyata $5 \%$.

\section{HASIL DAN PEMBAHASAN}

Peubah biomassa tanaman yang diamati antara lain: bobot basah tajuk/tanaman, bobot basah akar/tanaman, bobot kering tajuk/tanaman, dan bobot kering akar/tanaman (Tabel 1). Secara keseluruhan, pemberian naungan nyata lebih rendah mempengaruhi komponen biomassa tanaman bawang dayak $(\mathrm{P}<0.05)$. Naungan menghasilkan bobot biomassa tanaman (basah dan kering) yang lebih rendah dibandingkan tanpa naungan. Naungan $75 \%$ memberikan bobot kering tajuk (2,6 kali) dan akar (3,6 kali) lebih rendah dibandingkan perlakuan tanpa naungan.

Menurunnya biomassa tajuk (basah dan kering) tanaman bawang dayak disebabkan pertumbuhan tanaman di bawah naungan $75 \%$ lebih diarahkan untuk pertumbuhan tinggi tanaman sehingga pertumbuhan jumlah daun juga 
Tabel 1. Pengamatan bobot basah dan kering biomassa tanaman bawang dayak pada perlakuan naungan

\begin{tabular}{lcccc}
\hline Perlakuan & $\begin{array}{c}\text { Bobot basah tajuk } \\
\left(\mathrm{g}^{-1} \text { tanaman }\right)\end{array}$ & $\begin{array}{c}\text { Bobot basah akar } \\
\left(\mathrm{g}^{-1} \text { tanaman }\right)\end{array}$ & $\begin{array}{c}\text { Bobot kering tajuk } \\
\left(\mathrm{g}^{-1} \text { tanaman }\right)\end{array}$ & $\begin{array}{c}\text { Bobot kering akar } \\
\left(\mathrm{g}^{-1} \text { tanaman }\right)\end{array}$ \\
\hline Tanpa naungan & $136,6 \mathrm{a}$ & $32,5 \mathrm{a}$ & $33,5 \mathrm{a}$ & $4,3 \mathrm{a}$ \\
Naungan 75\% & $71,7 \mathrm{~b}$ & $10,7 \mathrm{~b}$ & $12,9 \mathrm{~b}$ & $1,2 \mathrm{a}$ \\
\hline
\end{tabular}

Keterangan: Angka-angka pada kolom yang sama yang diikuti oleh huruf yang berbeda menunjukkan berbeda nyata pada uji $t$-student dengan taraf nyata $5 \%$; KK: Koefisien keragaman

Tabel 2. Respon pertumbuhan jumlah anakan dan komponen produksi tanaman bawang dayak pada perlakuan naungan

\begin{tabular}{lccc}
\hline Perlakuan & Jumlah anakan & $\begin{array}{c}\text { Jumlah umbi per } \\
\text { tanaman }\end{array}$ & $\begin{array}{c}\text { Bobot umbi } \\
\left(\mathrm{g}^{-1} \text { tanaman }\right)\end{array}$ \\
\hline Tanpa naungan & $15,4 \mathrm{a}$ & $21,6 \mathrm{a}$ & $67,4 \mathrm{a}$ \\
Naungan 75\% & $6,7 \mathrm{~b}$ & $8,9 \mathrm{~b}$ & $19,7 \mathrm{~b}$ \\
\hline
\end{tabular}

Keterangan: Angka-angka pada kolom yang sama yang diikuti oleh huruf yang berbeda menunjukkan berbeda nyata pada uji $t$-student dengan taraf nyata 5\%; KK: Koefisien keragaman

Tabel 3. Hasil analisis total flavonoid umbi bawang dayak pada perlakuan naungan

\begin{tabular}{lc}
\hline Perlakuan & Total flavonoid (\%) \\
\hline Tanpa naungan & $0,0978 \mathrm{a}$ \\
Naungan $75 \%$ & $0,1230 \mathrm{a}$ \\
\hline
\end{tabular}

Keterangan: Angka-angka pada kolom yang sama yang diikuti oleh huruf yang berbeda menunjukkan berbeda nyata pada uji $t$-student dengan taraf nyata 5\%; KK: Koefisien keragaman

menjadi menurun. Sejalan dengan menurunnya jumlah daun, maka bobot tajuk baik basah dan kering juga akan menurun.

Hasil penelitian (Rezai, Etemadi, Nikbakht, Yousefi, \& Majidi, 2018) menunjukkan bahwa naungan $70 \%$ menghasilkan jumlah daun sage yang lebih sedikit, tetapi bobot basah dan kering daun lebih tinggi dibandingkan tanpa naungan (0\%). Penelitian dari (Asbur et al., 2019) juga menyatakan bahwa naungan $50 \%$ menurunkan bobot kering Asystasia gangetica dibandingkan tanpa naungan.

Pada waktu pemanenan di umur tanaman 17 MST, peubah yang diamati adalah jumlah anakan dan komponen produksi tanaman. Komponen produksi tanaman meliputi: jumlah umbi per tanaman dan bobot umbi per tanaman (Tabel 2). Hasil uji $t$-student menunjukkan bahwa perlakuan naungan memberikan pengaruh yang nyata lebih rendah $(\mathrm{P}<$ 0.05) terhadap peubah jumlah anakan dan komponen produksi tanaman. Pemberian naungan $75 \%$ menurunkan jumlah anakan bawang dayak. Naungan $75 \%$ menghasilkan jumlah anakan 2,3 kali lebih sedikit dibandingkan perlakuan tanpa naungan.

Respon jumlah umbi dan bobot umbi per tanaman bawang dayak nyata lebih rendah oleh perlakuan naungan (P $<0.05)$. Naungan menghasilkan jumlah umbi dan bobot umbi per tanaman yang lebih rendah dibandingkan bawang dayak yang tidak ternaungi. Naungan $75 \%$ menghasilkan jumlah umbi per tanaman (2,4 kali) dan bobot umbi per tanaman $(3,4$ kali) lebih sedikit dibandingkan tanpa naungan.

Jumlah anakan, jumlah dan bobot umbi per tanaman bawang dayak pada perlakuan naungan $75 \%$ lebih sedikit dibandingkan dengan tanpa naungan diduga karena hasil fotosintesis lebih diarahkan untuk pertumbuhan dan perkembangan vegetatif tanaman, khususnya tinggi tanaman dan ukuran daun yang semakin panjang sehingga jumlah anakan dan komponen produksi tanaman menjadi terhambat.
Beberapa penelitian juga menunjukkan hasil yang serupa bahwa adanya naungan menurunkan produksi tanaman, seperti pada bawang tiwai (Purwanti \& Taryono, 2018), bunga Rosa damascena Mill. (Thakur, Bhatt, \& Kumar, 2019), dan pegagan (Tripatmasari, Wasonowati, \& Alianti, 2010).

Hasil uji t-student menunjukkan bahwa perlakuan naungan $75 \%$ tidak mempengaruhi kandungan total flavonoid umbi bawang dayak $(\mathrm{P}>0.05)$. Naungan memberikan kandungan total flavonoid umbi bawang dayak yang tidak berbeda dengan perlakuan tanpa naungan (Tabel 3). Namun demikian, pemberian naungan menghasilkan kandungan total flavonoid 1,3 kali lebih tinggi dibandingkan perlakuan tanpa naungan. Kelompok senyawa fenolik terbesar pada tanaman, salah satunya adalah flavonoid (Taiz \& Zeiger, 2012). Kandungan total flavonoid setiap jenis tanaman, baik tanaman senang cahaya matahari (sun plant) maupun tanaman ternaungi (shade plant) menunjukkan hasil yang berbeda-beda (Idris, C. Linatoc, Mustapha Muhammad, Muhammad Aliyu, \& Abu Bakar, 2018). Tanaman jahe memiliki kandungan flavonoid lebih tinggi pada kondisi ternaungi (Ghasemzadeh, Jaafar, Rahmat, Wahab, \& Halim, 2010). Akumulasi flavonoid tertinggi tanaman lada (Pacheco et al., 2014) dan Lithocarpus litseifolius memerlukan naungan sedang (Li et al., 2016). Sebagai contoh, kandungan flavonoid yang tinggi pada kondisi ternaungi karena terjadi peningkatan aktivitas enzim PAL (phenylalanine ammonia lyase) yang akan diikuti oleh peningkatan kandungan fenolik. Flavonoid adalah bagian dari kelompok besar senyawa fenolik dalam lintasan fenilpropanoid. Peningkatan kandungan flavonoid juga ditunjukkan dari hasil penelitian (Linatoc, Idris, Fadzelly, \& Bakar, 2018) bahwa kandungan fenolik dan flavonoid pada daun tanaman mangga lebih tinggi dibandingkan daun yang tidak ternaungi. Hal yang 
berbeda ditunjukkan oleh (Wang et al., 2012) bahwa naungan paranet $(80 \pm 5 \%)$ menurunkan kandungan komponen flavonoid yaitu proantosianin dan $O$-glycosylated pada daun teh dibandingkan daun yang tidak ternaungi. Hasil penelitian lain menunjukkan bahwa kandungan antosianin pada tanaman padi (beras merah) meningkat pada tingkat naungan antara 50-75\% (Muhidin et al., 2018).

\section{KESIMPULAN}

Pemberian naungan $75 \%$ berpengaruh lebih rendah terhadap jumlah anakan dan komponen produksi tanaman bawang dayak. Naungan menurunkan bobot basah dan kering biomassa tanaman (tajuk dan akar), jumlah anakan, jumlah umbi/tanaman, dan bobot umbi/tanaman. Kandungan total flavonoid tidak dipengaruhi oleh naungan.

\section{UCAPAN TERIMA KASIH}

Terima kasih disampaikan kepada Politeknik LPP yang telah memberikan dana untuk penelitian ini dalam Program Penelitian Hibah Kompetitif (PHKK) Tahun Anggaran 2019.

\section{DAFTAR PUSTAKA}

Asbur, Y., Purwaningrum, Y., Rambe, R. D. ., Kusbiantoro, D., Hendrawan, D., \& Khairunnisyah. (2019). Studi jarak tanam dan naungan terhadap pertumbuhan dan potensi Asystasia gangetica (L.) T. Anderson sebagai tanaman penutup tanah. Kultivasi, 18(3), 969-976. https://doi.org/https://doi.org/10.24198/kultivasi.v18i 3.21422

Audina, N. M., Maxiselly, Y., \& Rosniawaty, S. (2016). Pengaruh kerapatan naungan dan frekuensi penyiraman terhadap pertumbuhan bibit kemiri sunan (Reutealis trisperma (BLANCO) Airy Shaw). Kultivasi, 15(2), 70-73. https://doi.org/10.24198/kltv.v15i2.11901

Egra, S., Ayu Sekarsari, R., Kuspradini, H., \& Mitsunaga, T. (2019). Potential Of Dayak Onion (Eleutherine palmifolia (L.) Merr) extract as natural pesticide for bacteria causing Wilt Disease. INTERNATIONAL JOURNAL OF SCIENTIFIC \& TECHNOLOGY RESEARCH, 8(11), 244-248. Retrieved from www.ijstr.org

Galingging, R. . (2009). Bawang Dayak (Eleutherine palmifolia) sebagai tanaman obat multifungsi. Warta Penelitian Dan Pengembangan Tanaman Industri, 15(3), 2-4.

Ghasemzadeh, A., Jaafar, H. Z. E., Rahmat, A., Wahab, P. E. M., \& Halim, M. R. A. (2010). Effect of different light intensities on total phenolics and flavonoids synthesis and anti-oxidant activities in young ginger varieties (Zingiber officinale Roscoe). International Journal of
Molecular Sciences, 11(10), 3885-3897. https://doi.org/10.3390/ijms11103885

Handriawan, A., Respatie, D. W., \& Tohari. (2016). Pengaruh intensitas naungan terhadap pertumbuhan dan hasil tiga kultivar kedelai (Glycine max (L.) Merrill) di lahan pasir Pantai Bugel, Kulon Progo. Vegetalika, 5(3), 1-14. https://doi.org///doi.org/10.22146/veg.25346

Idris, A., C. Linatoc, A., Mustapha Muhammad, S., Muhammad Aliyu, A., \& Abu Bakar, M. F. (2018). Effect of Light Intensity on the Total Flavonoid and Total Phenolic Contents of Mikania Micrantha and Tridax Procumbens. Journal of Science and Technology, 10(4). https://doi.org/10.30880/jst.2018.10.04.001

Karimi, E., Jaafar, H. Z. E., Ghasemzadeh, A., \& Ibrahim, M. H. (2013). Light intensity effects on production and antioxidant activity of flavonoids and phenolic compounds in leaves, stems and roots of three varieties of Labisia pumila benth. Australian Journal of Crop Science, 7(7), 1016-1023.

Li, A., Li, S., Wu, X., Zhang, J., He, A., Zhao, G., \& Yang, X. (2016). Effect of light intensity on leaf photosynthetic characteristics and accumulation of flavonoids in Lithocarpus litseifolius (Hance) Chun. (Fagaceae). Open Journal of Forestry, 06(05), 445459. https://doi.org/10.4236/ojf.2016.65034

Linatoc, A. C., Idris, A., Fadzelly, M., \& Bakar, A. (2018). Influence of Light Intensity on the Photosynthesis and Phenolic Contents of Mangifera Indica Influence of Light Intensity on the Photosynthesis and Phenolic Contents of Mangifera Indica. (December). https://doi.org/10.30880/jst.2018.10.04.009

Meda, A., Euloge, C., Romito, M., Millogo, J., \& Germaine, O. (2005). Food Chemistry Determination of the total phenolic, flavonoid and proline contents in Burkina Fasan honey, as well as their radical scavenging activity. $91, \quad 571-577$. https://doi.org/10.1016/j.foodchem.2004.10.006

Muhidin, Syam'un, E., Kaimuddin, Musa, Y., Sadimantara, G. R., Usman, ... Rakian, T. C. (2018). The effect of shade on chlorophyll and anthocyanin content of upland red rice. IOP Conference Series: Earth and Environmental Science, 1-5. https://doi.org/10.1088/1755-1315/122/1/012030

Naspiah, N., Iskandar, Y., \& Moelyono, M. W. (2014). Artikel Ulasan: Bawang Tiwai ( Eleutherine americana Merr .), Tanaman multiguna. Indonesian Journal of Applied Sciences, 4(2), 18-30. https://doi.org/https://doi.org/10.24198/.v4i2.16820 
Pacheco, F. V., Alvarenga, I. C. A., Junior, P. M. R., Pinto, J. E. B. P., Avelar, R. de P., \& Alvarenga, A. A. (2014). Growth and production of secondary compounds in monkey-pepper ( Piper aduncum L .) leaves cultivated under altered ambient light. Australian Journal of Crop Science, 8(11), 1510-1516. Retrieved from http://www.cropj.com/pacheo_8_11_2014_1510_151 6.pdf

Pradana, D. P., Putri, B., \& Hudaidah, S. (2017). Pengaruh intensitas cahaya terhadap pertumbuhan dan kandungan karotenoid Dunaliella sp. pada media ekstrak daun lamtoro Leucaena leucocephala. Scripta Biologica, 4(4), 263-267. https://doi.org/10.20884/1.sb.2017.4.4.626

Prasetya, M. E. (2014). Pengaruh pupuk NPK Mutiara dan pupuk kandang sapi terhadap pertumbuhan dan hasil tanaman cabai merah keriting varietas Arimbi (Capsicum annuum L.). Jurnal AGRIFOR Volume XIII Nomor, XIII(2), 191-198.

Prayitno, B., Mukti, B. H., \& Lagiono. (2018). Optimasi potensi bawang dayak (Eleutherine sp.) sebagai bahan obat alternatif. Jurnal Pendidikan Hayati, 4(3), 149158.

https://doi.org/https://doi.org/10.33654/jph.v4i3.436

Purwanti, N. H., \& Taryono. (2018). Purwanti dan Taryono 2018. Agrinova: Journal of Agriculture Inovation, 1(2), 056-060.

Puspadewi, R., Adirestuti, P., \& Menawati, R. (2013). Khasiat umbi bawang dayak (Eleutherine palmifolia (L.) Merr. sebagai herbal antimikroba kulit. Kartika Jurnal Ilmiah Farmasi, 1(1), 31-37. https://doi.org/10.26874/kjif.v1i1.33-40

Rezai, S., Etemadi, N., Nikbakht, A., Yousefi, M., \& Majidi, M. M. (2018). Effect of light intensity on leaf morphology, photosynthetic capacity, and chlorophyll content in sage (Salvia officinalis L.). Horticultural Science and Technology, 36(1), 46-57. https://doi.org/10.12972/kjhst.20180006

Taiz, L., \& Zeiger, E. (2012). Lincoln Taiz. In Plant Physiology (Fifth Edit, p. 623 p). Sinauer Associates Inc., Publishers Sunderland, Massachusetts U.S.A.

Thakur, M., Bhatt, V., \& Kumar, R. (2019). Effect of shade level and mulch type on growth, yield and essential oil composition of damask rose (Rosa damascena Mill.) under mid hill conditions of Western Himalayas. PLoS $O N E$, 14(4). https://doi.org/10.1371/journal.pone.0214672

Tripatmasari, M., Wasonowati, C., \& Alianti, V. R. (2010). Pemanfaatan Naungan Dan Pupuk Kotoran Sapi Terhadap. Agrovivor, 3(2), 137-145.

Wang, Y. S., Gao, L. P., Shan, Y., Liu, Y. J., Tian, Y. W., \& Xia, T. (2012). Influence of shade on flavonoid biosynthesis in tea (Camellia sinensis (L.) O. Kuntze). Scientia Horticulturae, 141, 7-16. https://doi.org/10.1016/j.scienta.2012.04.013

Wijayanti, S. D., \& Hasyati, N. (2018). Potensi Ekstrak Umbi Bawang Dayak (Eleutherine palmifolia (L.) Merr.) Dalam Mencegah Ulcerative Colitis Pada Mencit Yang Diinduksi DSS (Dextran Sulphate Sodium). Jurnal Ilmu Pangan Dan Hasil Pertanian, 2(1), 40-52.

Wulandari, I., Haryanti, S., \& Izzati, M. (2016). Pengaruh naungan menggunakan paranet terhadap pertumbuhan serta kandungan klorofil dan $\beta$ karoten pada kangkung darat (Ipomoea reptans Poir.). Jurnal Biologi, 5(3), 7179. Retrieved from https://ejournal3.undip.ac.id/index.php/biologi/article/ view/19505

Zhu, H., Li, X., Zhai, W., Liu, Y., Gao, Q., Liu, J., ... Zhu, Y. (2017). Effects of low light on photosynthetic properties, antioxidant enzyme activity, and anthocyanin accumulation in purple pak-choi (Brassica campestris ssp. Chinensis Makino). PLoS ONE, 12(6). https://doi.org/10.1371/journal.pone.0179305 